Lavrinenko, V., Sheiko, M., Paschenko, E., and Riabchenko, S.

Bakul Institute for Superhard Materials of the NAS of Ukraine, 2, Avtozavodska St., Kyiv, 04074, Ukraine,

+380 44432 9515, lavrinenko@ism.kiev.ua

\title{
ELABORATION OF TECHNOLOGY FOR MAKING HIGH-POROUS ABRASIVE WHEELS OF MONOCRYSTALLINE CORUND OF THE EUROPEAN NOMENCLATURE USING A PRECISION INSTRUMENT OF SUPERHARD MATERIALS FOR TURBO-BUILDING OF UKRAINE
}

Introduction. In order to increase the precision, productivity, and environment safety of production domestic turbinebuilding corporations purchase new European equipment and European nomenclature high-porous abrasive wheels using monocrystalline corundum.

Problem Statement. The monocrystalline corundum wheels significantly differ from ordinary ones in terms of their highprecision trueing.

Purpose. To elaborate a technology for precision shaping of European nomenclature abrasive wheels using a tool made of superhard materials created in Ukraine for the needs of turbine-building corporations of Ukraine and import substitution of such tools.

Materials and Methods. The method for weighing and hydrostatic weighing of fragments of abrasive material of new European nomenclature grinding wheels(Best-Business c. s); mathematical simulation of balancing the volumes of grinding material, binder, and pores; and spectral analysis of the polished surface of the studied wheel samples have been used.

Results. The structure of studied wheels has been identified; it has been harmonized with GOST 2424-83 applicable in Ukraine. A correlation between the initial characteristics of wheels, the diamond tool, the shaping modes and the nature of tool wear and tool life has been established. The parameters of shaping the monocrystalline corundum wheels have been optimized. Samples of the trueing and grinding tools from diamond and cubic boron nitride have been made and delivered for pilot tests to turbine-building corporations in Ukraine. The rollers 400/315 AC200T made using the electroforming method have done 6.5 thousand trueing operations, $0.3 \mathrm{~mm}$ each. The state of working surface remains perfect and there are no grounds to talk about the end of toll life.

Conclusion. The technology for precision shaping of European nomenclature abrasive wheels has been worked out using tools of superhard materials created in Ukraine, namely, in the Bakul Institute of Superhard Materials of the NAS of Ukraine, which have proven their high efficiency.

Keywords: precision tool, highly porous abrasive wheels, abrasive wheels of the European nomenclature, monocrystalline corundum, and turbine building.

Modern engine construction is one of the most knowledge-intensive branches of machine building in Ukraine and worldwide. The market demand for gas turbine engines is known to grow

(C) LAVRINENKO, V., SHEIKO, M., PASCHENKO, E., and RIABCHENKO, S., 2018 constantly. Moreover, the scope of application of such engines is not limited to aviation. Today, they are used in oil and gas extraction, transport, shipbuilding, and power engineering. Currently, the main directions in the engine design is to increase their technical characteristics and effi- 


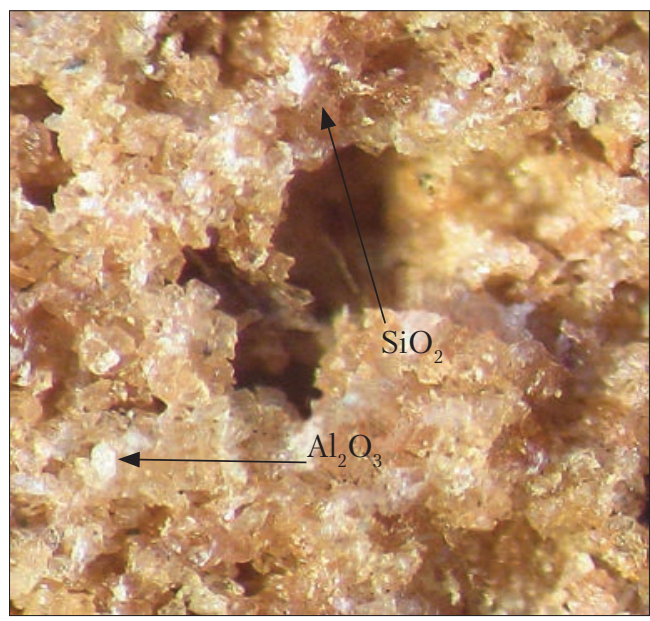

Fig. 1. Typical view of developed (polished) surface of abrasive material sample of monocrystalline corundum wheels (wheel ПП $500 \times 32 \times 305$ A99)

ciency, mainly, due to the application of advanced technology for engine production, tools, and materials and efficient machining techniques.

To date, the plants have used abrasive wheels manufactured in Russian Federation, but today, in order to increase their precision, productivity, and environmental friendliness, they have been substantially upgraded with new European equipment for which it is necessary to use the European nomenclature high-porous abrasive wheels of monocrystalline corundum. This abrasive tool reduces significantly (almost three times) the volumetric composition of abrasive grains with the porosity increasing up to $64 \%$ of the grinding wheel volume (Fig. 1). These grinding wheels are notable for a unique combination of a high structuredness (up to 22 developed abrasive ceramic compositions) with the use of abrasive material based on monocrystalline corundum obtained by the sol-gel technology (SGtechnology). Such abrasive tools enable to work in essentially different thermal power conditions, to achieve better access of cooling liquids to the processing area, to increase the productivity, and to improve the quality of processing.

The technological problem is that the aforementioned high-porosity abrasive wheels of the European nomenclature have significant diffe- rences in their high-precision trueing, and therefore there is a need to work out the technology for their precision trueing, to clarify the characteristics of diamond trueing tool and the characteristics of tool made of super-hard materials. The purpose of this research is to develop the technology for precision trueing of high-porous monocrystalline abrasive wheels of the European nomenclature using a tool made of super-hard materials created in Ukraine, namely, at the Bakul Institute of Superhard Materials of the NAS of Ukraine, for the needs of turbine industry of Ukraine in order to replace the imported instrument.

In order to achieve this, a number of problems have to be solved. Firstly, the structure of the studied wheel has been identified, in accordance with GOST 2424-83 applicable in Ukraine. According to GOST 21445, the structure of the abrasive tool is the ratio of the volumes of grinding material, binder, and pores. The theory of abrasive tool manufacture developed in the early 1950s recommends to determine the volume content of binder $V_{\mathrm{b}}, \%$ using the formula:

$$
V_{\mathrm{b}}=-11,5+1,5 N+2 n,
$$

where $n$ is the structure number, $N$ is the hardness number. The hardness number of the abrasive tool is a digital indication of hardness degree used in calculating the binder and pore volumes. The hardness degree VM1 is assigned with number $0, \mathrm{VM} 2$ is assigned with number 1 , etc. The last hardness degree CHT2 is marked with 17.

The actual structure of wheels is known not always to correspond to this dependence. Moreover, according to Internet resources and catalogs of foreign abrasive grinding tools, each of the leading instrumental manufacturers interprets the term "structure" for its products in different way.

The actual structure of mentioned wheels made of monocrystalline corundum, of white electro corundum, and of electrically painted electro corundum has been established by the method for measuring the linear dimensions of the cases 
Best-Business c. $s$ Nominal and Actual Parameters of Wheel Structure $\left(A_{3}=10, n=12\right)$

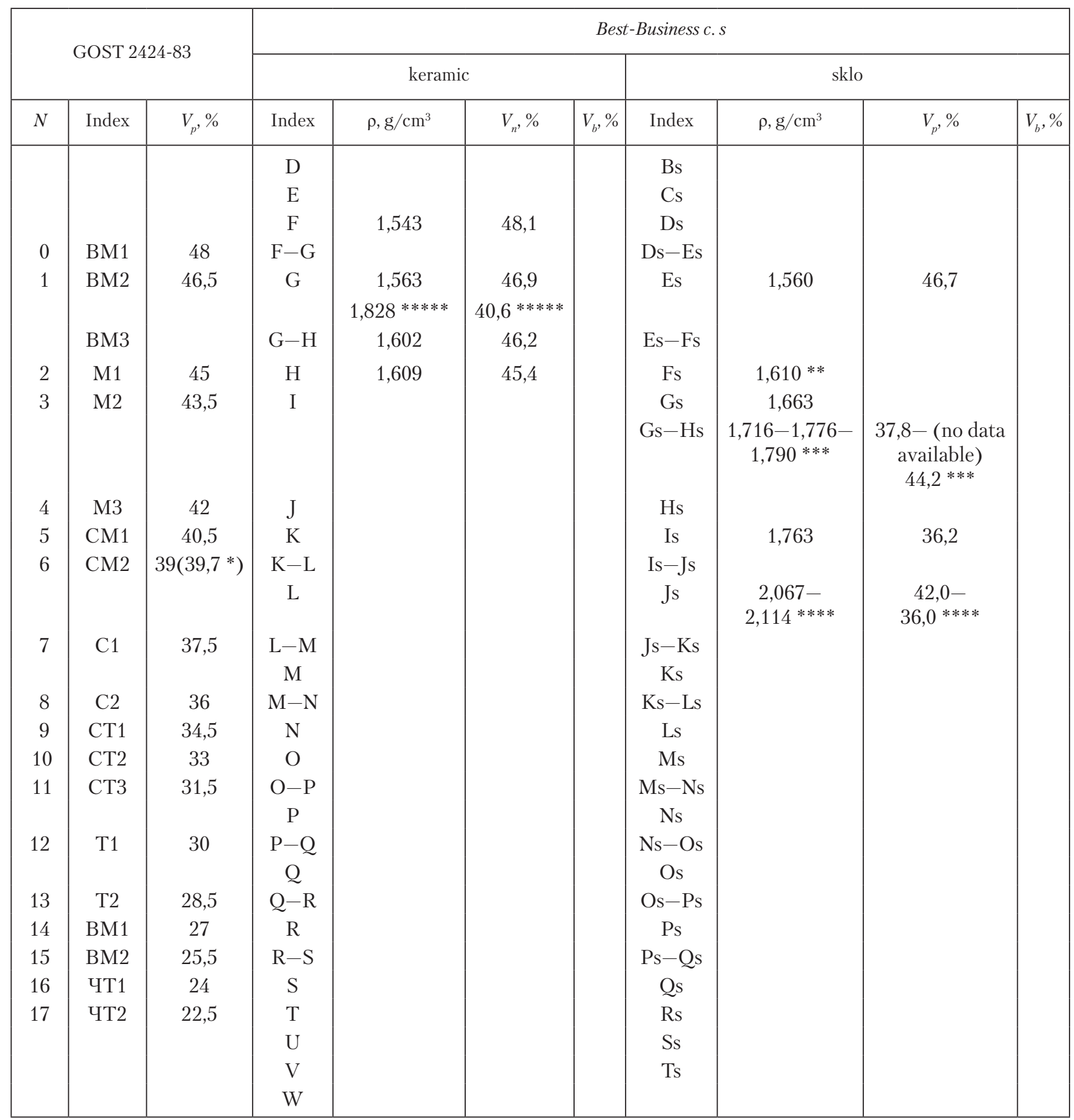

* - measured for grain size $A_{3}=25\left(A_{3}-\right.$ grain size $)$; * - for the structure $n=14 ; * *$ - дfor grain sizes $A_{3}=10,25$ and 40 , respectively; $* * * *$ for the structure $n=7$ and $n=4 ; * * * *-$ for $A_{3}=12, n=11$, monocrystalline corundum.

of abrasive grinding wheels of new European nomenclature (Best-Business c.s) with an accuracy of $0.1 \mathrm{~mm}$ (relative accuracy of $10^{-4}$ ), ), by weighing and hydrostatic weighing of fragments of abrasive material with an accuracy of $\pm 2 \mathrm{~g}$ (relative accuracy $10^{-3}$ ), as well as by mathematical modeling of the balance of grinding material, binder and pore volumes. In addition, a spectral 


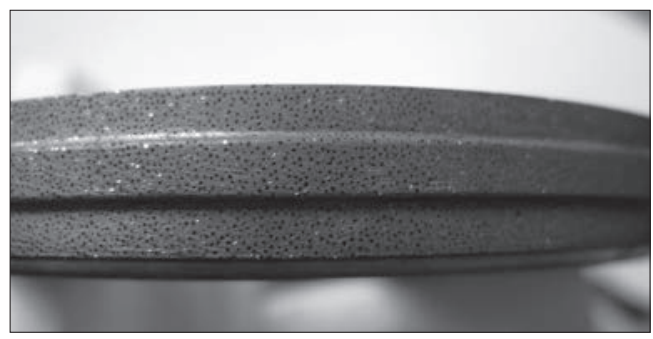

Fig. 2. Diamond trueing roller Ø125 400/315 AC200T, view from cylindrical surface: the middle extension is working part, the two external lowered ones are bases

analysis of the polished surface of wheel abrasive material samples has been done (Fig. 1). The results are summarized in Table below, where the actual hardness numbers, structure, and grain size of the grinding wheels of the European class are aligned with GOST 2424-83 applicable in Ukraine and the CIS countries.

The analysis of the actual densities of the above mentioned abrasive wheels, in particular, those made of monocrystalline corundum, has shown that the pore volume $V_{\mathrm{p}}$ and the wheel abrasive grain volume $V_{\mathrm{b}}$, calculated for the declared $n$ and $N$, do not correspond to the values given in the standards applicable in Ukraine. However, it should be noted that the actual structure of the abrasive wheels for the same parameters in the catalogs of various foreign manufacturers differs. GOST 2424-83 does not cover the actual, wider range of parameters of the abrasive wheels of new European nomenclature. Therefore, corresponding amendments and modifications to the relevant standards will be proposed. In addition, the correlation between the sound index and other parameters characterizing the hardness of grinding wheels of the European class has been established based on the above data:

$$
\begin{gathered}
Z i=75,5-6,9 \cdot h, h=10,6-0,14 Z i, \\
h=5,3 \mathrm{e}^{-0,19 \cdot N}+2,3, E=23,9+4,1 N, \mathrm{kH} / \mathrm{M}^{2}, \\
H B=85,8 \cdot \mathrm{e}^{0,203 \cdot N}, \mathrm{H} / \mathrm{M}^{2},
\end{gathered}
$$

where $Z i-$ is the wheel sound index (the abrasive material sound speed reduced 100 times), $h$ is the depth of the hole, mm (the jet blast crater), $E$ is Young's modulus of abrasive material, $H B$ is Brinell hardness, $N$ is the wheel hardness number according to GOST 2424-83.

Secondly, the correlation between the output characteristics of high-porous wheels and precision diamond tool, the formation modes, on the one hand, and the nature of the tool wear and the period of its stability, on the other hand has been established. Similarly to the tests of electro corundum wheels on ceramic binders of "ceramic reference" and "glass reference" types, the monocrystalline corundum wheels on ceramic binders of the "ceramic reference" type have been tested on a stand created based on machine 3B151, according to the scheme that simulates plunge trueing in modes close to production. The trueing tool is a diamond roll having a diameter of Ø125 and made in the Bakul Institute of Superhard Materials of the NAS of Ukraine by electroplating with diamond powder 400/315 AC200T (Fig. 2). The trueing mode parameters are as follows: average speed of the wheel is $26 \mathrm{~m} / \mathrm{s}$, that of the roller is $14.4 \mathrm{~m} / \mathrm{s}$, climb cut, ratio of speeds +1.8 , feed to a depth of $2.5 \mu$ m per wheel turn.

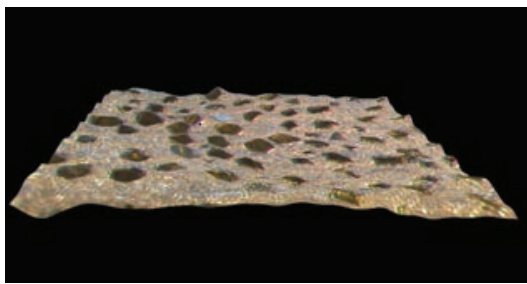

АГП 200Т 400/315 (після розкриття до питомого об'єму кишень): $\omega=(40 \pm 4) \cdot 10^{-3} \mathrm{MM}^{3} / \mathrm{MM}^{2}$

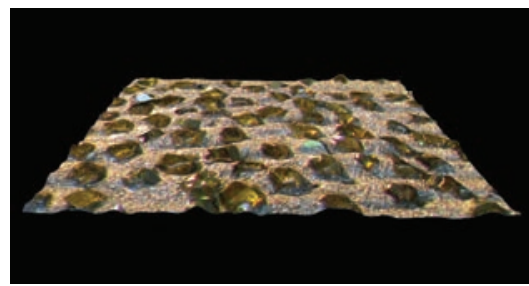

Дисперговано 3 у.о. матеріалу $G_{s} / H_{s}$ : $\omega=(59 \pm 4) \cdot 10^{-3} \mathrm{MM}^{3} / \mathrm{MM}^{2}$

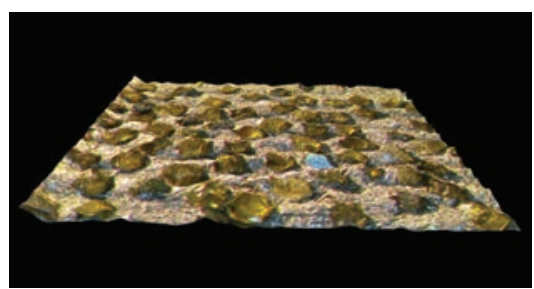

Диспергировано 6 у.о. матеріалу $G_{s} / H_{s}$ : $\omega=(65 \pm 2) \cdot 10^{-3} \mathrm{MM}^{3} / \mathrm{MM}^{2}$

Fig. 3. Typical dynamics of topography of work surface of trueing rollers Ø125 400/315 AC200T 
During the tests, the linear wear of the roller diamond layer and the wear of the binder according to the original method have been measured. The total volume of dispersed wheels according to the given scheme is equivalent to the volume of more than 9 wheels having a size of $600 \times 63 \times$ $\times 305$ in the plunge trueing mode. The volume of one wheel of this size was taken as conventional unit of the dispersed abrasive material volume.

While dispersing the abrasive material, the state of the working surface of the reference rollers was recorded. The typical dynamics of the working surface topography are shown in Fig. 3. The main practical task of the research is to study the influence of a new modification of the abrasive cutting grain material - monocrystalline corundum, on the service life and wear of diamond trueing rollers. As a result, no significant effect has been found. The trueing rollers 400/315 AC200T made by electroplating are dispersed on each volume larger than 9 conventional units, which corresponds to 6.5 thousand trueing operations, $0.3 \mathrm{~mm}$ each. In this case, the working surface remains perfect and there is no reason to assume the end of the period of stability.

Thirdly, optimal parameters for precision shaping of high-porous monocrystalline corundum wheels with given characteristics have been recommended. For manufacturing the trueing rollers, the hardest binders are used. Among them, the most widespread is nickel galvanic binder. Requirements for diamond powder: very durable, with a critical load ranging from 100 to $200 \mathrm{~N}$. The grain size of diamonds for the trueing tool varies from $250 / 200$ to $1000 / 800$. Powders with smaller particles are intended for the manufacture of small profiles, while those with larger size are used for flat profiles without sharp edges. It has been established that the larger the diamond powder, the higher the roller stability. However, taking into consideration the above, it is noted that the service life of trueing rollers manufactured at the Bakul Institute of Superhard Materials of the NAS of Ukraine by electroplating, 400/315 AC200T is, at least, 6.5 thousand trueing

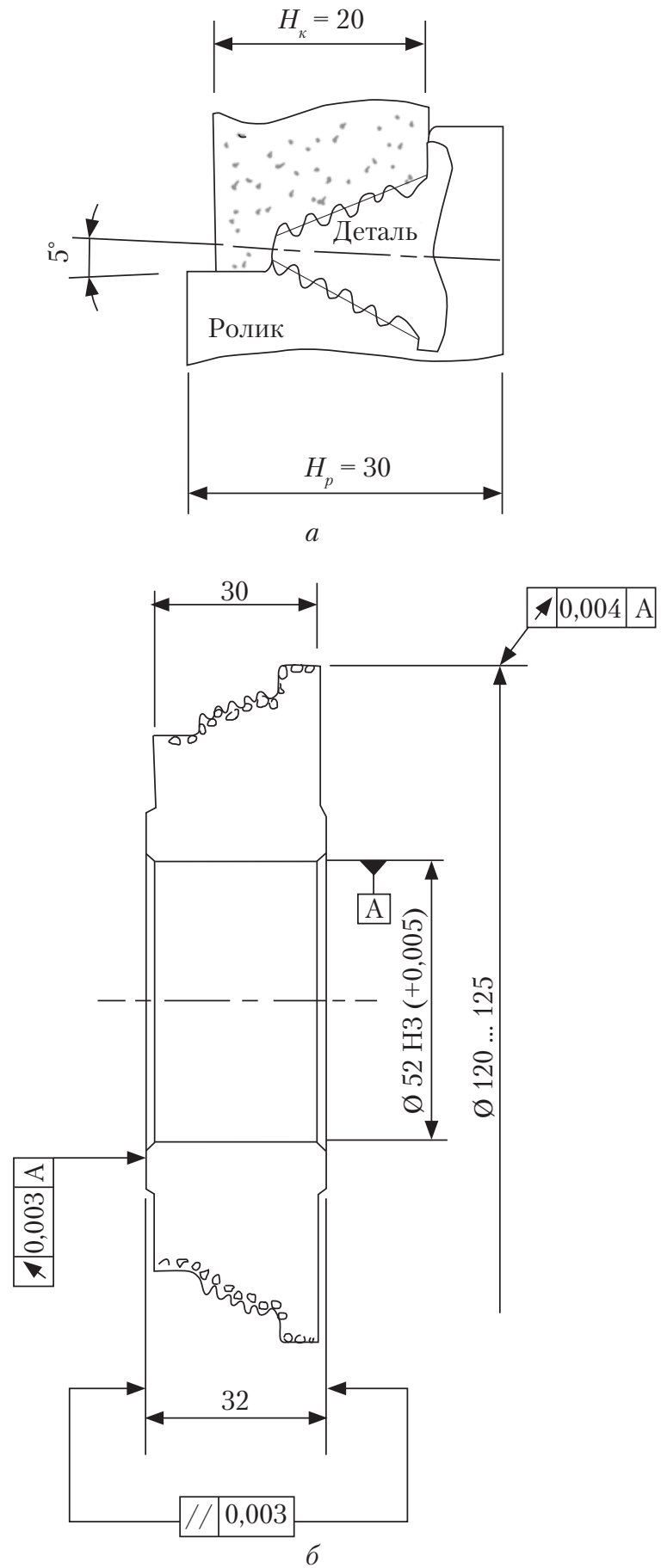

Fig. 4. Flowchart of trueing and dimensions of wedge-profile diamond roller designed for turbine blade root: $a$ - схема правки і шліфування $\left(H_{p}-\right.$ roller height, $H_{\kappa}-$ wheel height); $\sigma-$ ролик алмазний правлячий (для замкової частини лопатки) 


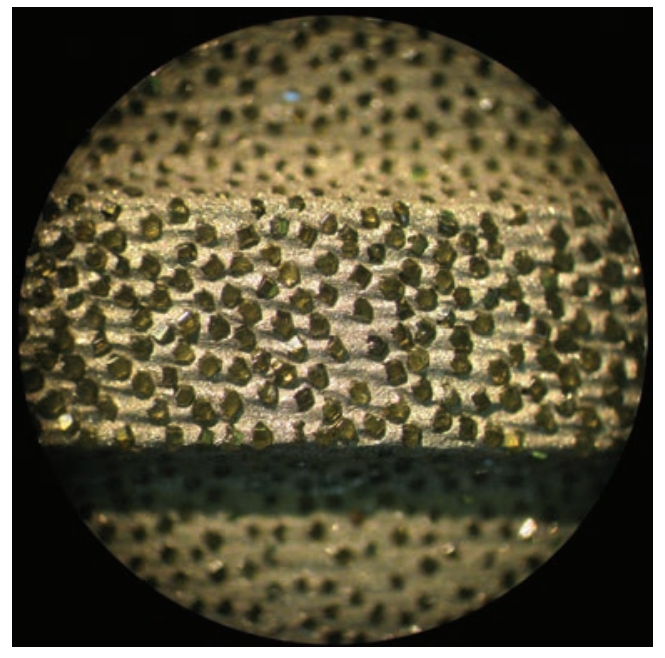

Fig. 5. Developed surface of diamond trueing roller Ø125 400/315 AC200T

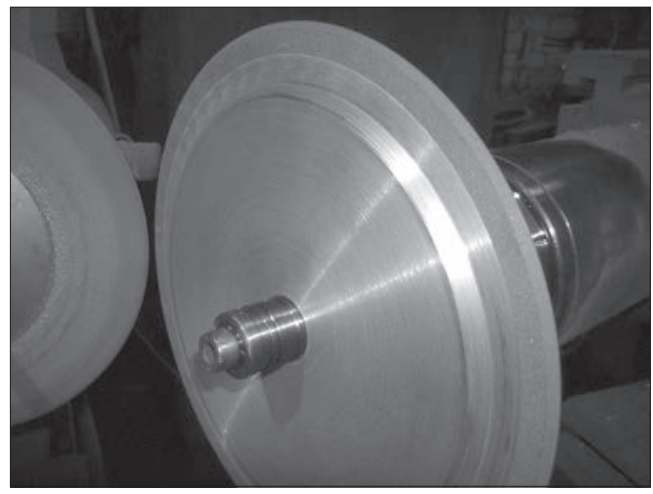

Fig. 6. BCN wheels, shape 14E1, diameter $200 \times$ $10 \times 3 \times 20 \times 45^{\circ}$

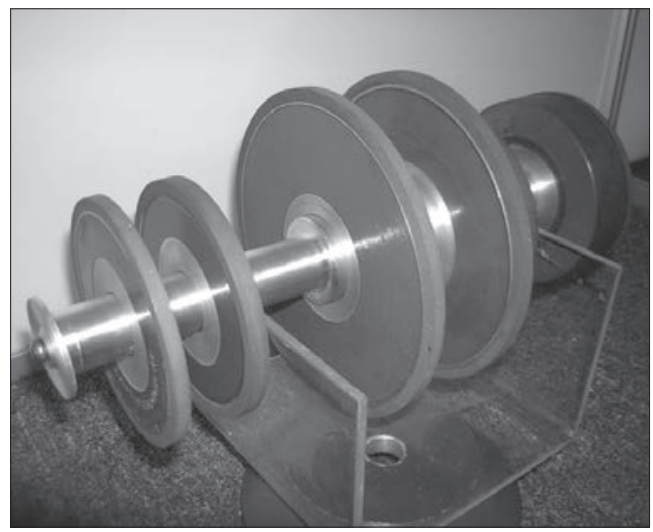

Fig. 7. Diamond abrasive wheel, shape 1A1 operations, $0.3 \mathrm{~mm}$ each, and no statistically significant effect of new modification of the abrasive cutting grain material (monocrystalline corundum) on the service life and wear of diamond trueing rollers has been established. Therefore, there is no reason to use an unreasonably large grain size, but it is necessary to proceed from the feasibility of ensuring the given accuracy of the complex shaped profile.

Within the framework of this research, the most typical profiles of surfaces machined at the plants of turbine industry of Ukraine (Fig. 4), in respect of which the technological features of the diamond trueing precision tool are established, have been analyzed. At the Bakul Institute of Superhard Materials of the NAS of Ukraine, the technological preparation of production has been carried out and the electroplating technology for fixing diamonds having an optimal grain size and a high heat resistance (AS200T 400/3150) on the roller surface has been determined to achieve a high-performance work of loaded sections of the roller working profile (Fig. 5).

To ensure the formation of high-porous monocrystalline corundum wheels and to take into account the research carried out and production requirements of Zoria-Mashproekt Gas Turbine Engineering Research \& Production Complex, the Bakul Institute of Superhard Materials of the NAS of Ukraine has produced according to customer's drawings 0061P, 0158E, K615-2175, P76040109P, manufactured and handed over to Zoria-Mashproekt for testing the precision diamond rollers. The tests of diamond rollers have shown that the above mentioned trueing tool fully meets the technical requirements of the enterprise production process and provides the required accuracy of the profile. The radial motion variation is less than $5 \mu \mathrm{m}$, the face motion variation is $3 \mu \mathrm{m}$, the quality of the treated surface is $\mathrm{R}_{\mathrm{a}}<0.63$.

Samples of the trueing and grinding tool have been made of diamond and of cubic boron nitride $(\mathrm{CBN})$ and given for pilot production tests to the following enterprises of turbine industry of Uk- 
raine: Zoria-Mashproekt (Mykolaiv), IvchenkoProgress Motor Construction Design Bureau and Motor-Sich (Zaporizhia) in order to introduce the technology for shaping the abrasive high-porous monocrystalline corundum wheels at these enterprises. For example, upon request of ZoriaMashproekt, five diamond trueing rollers have been manufactured according to the enterprise drawings to ensure the wheel formation. A batch of CBN wheels (shape $14 \mathrm{E} 1200 \times 10 \times 3 \times 20 \times 45^{\circ}$ ) (10 pieces, Fig. 6) for Gemini CNC (computer numerically controlled) machine has been manufactured. They have been tested by grinding titanium alloy products for aircraft engines at $\mathrm{Mo}^{-}$ tor-Sich. Diamond grinding wheels (shape 1A1 $125 \mathrm{~mm}$ ) (Fig. 7) and 11V9 $75 \mathrm{~mm}$ (7 pieces) for Yunger CNC machine have been manufactured and tested by grinding the hard-alloy butt mills for the treatment of turbine blades. CBN grin- ding wheels (shape 1A1 $125 \mathrm{~mm}$ ) for Yunger CNC machines have been made and tested by grinding butt mills of high-speed steel. The diamond and CBN tools have been implemented at Motor-Sich and Ivchenko-Progress Zaporizhia Motor Construction Design Bureau, which is confirmed by respective certificates.

The Bakul Institute of Superhard Materials of the NAS of Ukraine has signed agreements on cooperation with the enterprises involved in the tests within the framework of the innovative $R \& D$ project of the NAS of Ukraine: Contract No. 58/2830 dated December 30, 2015, for the period till December 30, 2018, for the amount of UAH 1 million with Zoria-Mashroekt, and from Contract No. 2313 dated January 18, 2006, for the period till December 31, 2018, for the amount of UAH 6 million with Ivchenko-Progress.

Received 28.02.18

\footnotetext{
В.І. Лавріненко, М.М. Шейко, С.О. Пащенко, С.В. Рябченко

Інститут надтвердих матеріалів ім. В.М. Бакуля НАН України, вул. Автозаводська, 2, Київ, 04074, Україна, +38044 432 9515, lavrinenko@ism.kiev.ua
}

\author{
ВІДПРАЦЮВАННЯ ТЕХНОЛОГІЇ ФОРМОУТВОРЕННЯ \\ ВИСОКОПОРИСТИХ АБРАЗИВНИХ КРУГІВ ЄВРОПЕЙСЬКОЇ НОМЕНКЛАТУРИ \\ З МОНОКРИСТАЛІЧНОГО КОРУНДУ ПРЕЦИЗІЙНИМ ІНСТРУМЕНТОМ \\ З НАДТВЕРДИХ МАТЕРІАЛІВ ДЛЯ ТУРБОБУДУВАННЯ УКРАЇНИ
}

Вступ. Вітчизняні підприємства турбобудування для підвищення прецизійності, продуктивності та екологічності виробництва закупають нове європейське обладнання і високопористі абразивні круги європейської номенклатури з використанням монокристалічного корунду.

Проблематика. Монокорундові круги мають значні відмінності від звичайних у їх високоточному правленні.

Мета. Відпрацювання технології прецизійного формоутворення абразивних кругів європейської номенклатури інструментом з надтвердих матеріалів, створеним в Україні, для потреб підприємств турбобудування України та імпортозаміщення такого інструменту.

Матеріали й методи. Використано метод зважування й гідростатичного зважування фрагментів абразивного матеріалу шліфувальних кругів нової європейської номенклатури (Best-Business c. s), а також математичне моделюванням балансу об'ємів шліфувального матеріалу, зв'язки і пор. Застосовано спектральний аналіз шліфованої поверхні досліджуваних зразків кругів.

Результати. Ідентифіковано структуру досліджуваних кругів, поставлено їі у відповідність до ГОСТ 2424-83, що діє в Україні. Встановлено зв'язок між вихідними характеристиками кругів, алмазного інструмента, режимами формоутворення з характером зносу інструменту і періодом його стійкості. Оптимизовано параметри формоутворення монокорундових кругів. Виготовлено зразки правлячого та шліфувального інструменту з алмазу та кубічного нітриду бору та передано для дослідно-виробничих випробувань на підприємства турбобудування України. Ролики 400/315 AC200Т, виготовлені методом гальванопластики, здійснили 6,5 тис. правок по 0,3 мм. При цьому стан робочої поверхні залишився ідеальним, тобто стверджувати про закінчення періоду стійкості немає підстав. 
Висновки. Відпрацьовано технологію прецизійного формоутворення абразивних кругів європейської номенклатури інструментом з надтвердих матеріалів, створеним в Україні, а саме в Інституті надтвердих матеріалів ім. В.М. Бакуля НАН України, які довели свою високу ефективність.

Ключові слова: прецизійний інструмент, високопористі абразивні круги, абразивні круги європейської номенклатури, монокристалічний корунд, турбобудування.

\author{
В.И. Лавриненко, М.Н. Шейко, Е.А. Пащенко, С.В. Рябченко \\ Институт сверхтвердых материалов им. В.Н. Бакуля НАН Украины, \\ ул. Автозаводская, 2, Киев, 04074, Украина, \\ +380 44432 9515, lavrinenko@ism.kiev.ua

\section{ОТРАБОТКА ТЕХНОЛОГИИ ФОРМООБРАЗОВАНИЯ ВЫСОКОПОРИСТЫХ АБРАЗИВНЫХ КРУГОВ ЕВРОПЕЙСКОЙ НОМЕНКЛАТУРЫ ИЗ МОНОКРИСТАЛЛИЧЕСКОГО КОРУНДА ПРЕЦИЗИОННЫМ ИНСТРУМЕНТОМ ИЗ СВЕРХТВЕРДЫХ МАТЕРИАЛОВ ДЛЯ ТУРБОСТРОЕНИЯ УКРАИНЫ}

Введение. Отечественные предприятия турбостроение для повышения прецизионности, производительности и экологичности производства закупают новое европейское оборудование и высокопористые абразивные круги европейской номенклатуры с использованием монокристаллического корунда.

Проблематика. Монокорундовые круги имеют значительные отличия от обычных в их высокоточной правке.

Цель. Отработка технологии прецизионного формообразования абразивных кругов европейской номенклатуры инструментом из сверхтвердых материалов, созданным в Украине, для нужд предприятий турбостроение Украины и импортозамещения такого инструмента.

Материалы и методы. Использован метод взвешивания и гидростатического взвешивания фрагментов абразивного материала шлифовальных кругов новой европейской номенклатуры (Best-Business c. s), а также математическое моделирование баланса объемов шлифовального материала, связки и пор. Применен спектральный анализ шлифованной поверхности исследуемых образцов кругов.

Результаты. Идентифицирована структура исследуемых кругов, поставлено ее в соответствие с ГОСТ 2424-83, действующим в Украине. Установлена связь между исходными характеристиками кругов, алмазного инструмента, режимами формообразования с характером износа инструмента и периодом его стойкости. Оптимизированы параметры формообразования монокорундових кругов. Изготовлены образцы правящего и шлифовального инструмента из алмаза и кубического нитрида бора и переданы для опытно-производственных испытаний на предприятия турбостроения Украины. Ролики 400/315 АС200Т, изготовленные методом гальванопластики, произвели 6,5 тыс. правок по 0,3 мм. При этом состояние рабочей поверхности осталось идеальным, то есть утверждать об окончании периода стойкости нет оснований.

Выводы. Отработана технология прецизионного формообразования абразивных кругов европейской номенклатуры инструментом из сверхтвердых материалов, созданным в Украине, а именно в Институте сверхтвердых материалов им. В.М. Бакуля НАН Украины, которые доказали свою высокую эффективность.

Ключевые слова: прецизионный инструмент, высокопористые абразивные круги, абразивные круги европейской номенклатуры, монокристаллический корунд, турбостроение. 